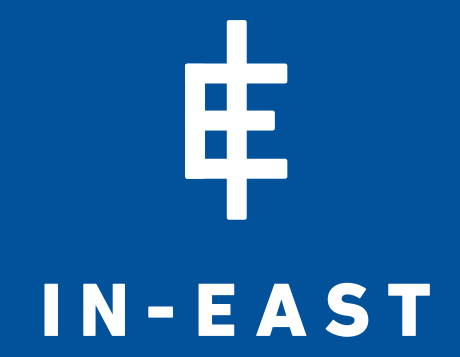

INSTITUTE OF EAST ASIAN STUDIES

YUAN LI

KIERSTIN BOLTON

THEO WESTPHAL

The Effect of the New Silk Road Railways on Aggregate Trade Volumes

between China and Europe

WORKING PAPERS

ON EAST ASIAN STUDIES 


\section{YUAN LI}

Corresponding author,

Acting Professor of Business and Economic Studies of East Asia, Institute of East Asian Studies

(IN-EAST), and Mercator School of Management, University of Duisburg-Essen.

W https://www.uni-due.de/in-east/people/li_yuan.php

Eyuan.li@uni-due.de

\section{KIERSTIN BOLTON}

Graduate Student, Institute of East Asian Studies (IN-EAST), University of Duisburg-Essen.

\section{THEO WESTPHAL}

Institute of East Asian Studies (IN-EAST), University of Duisburg-Essen.

\section{Institute of East Asian Studies / Institut für Ostasienwissenschaften}

University of Duisburg-Essen

Duisburg Campus, Forsthausweg

47057 Duisburg, Germany

$\mathbf{T}+49(0) 203379-4191$

$\mathbf{F}+49(0) 203379-4157$

Ein-east@uni-due.de

ISSN: 1865-8571 (Printed version) / 1865-858X (Internet version)

Download: www.uni-due.de/in-east/about_in-east/publications/

(c) by the authors, June 2016 


\section{CONTENT}

1 Introduction 5

2 An Introduction of Railway Connections and Sino-EU Trade 6

2.1 Patterns of Railway Connections between the Involved Countries 6

2.2 China-EU Trade 8

3 The Empirical Model 10

4 Data Collection and Analysis 11

5 Results 12

6 The Yuxinou Railway: Connecting Chongqing and Duisburg by Train 16

7 Conclusion 17

$\begin{array}{ll}\text { References } & 18\end{array}$ 
YUAN LI / KIERSTIN BOLTON / THEO WESTPHAL

\title{
The Effect of the New Silk Road Railways \\ on Aggregate Trade Volumes \\ between China and Europe
}

WORKING PAPERS ON EAST ASIAN STUDIES, NO. 109, DUISBURG 2016

\begin{abstract}
"One Belt, One Road" is an extensive and complex initiative whose potential effect and influence are still currently pending for answers. This paper addresses the following research question: What is the effect of the New Silk Road intercontinental railways on the trade between China and its trading partners in Central Asia and Europe? We focus on nine railway lines connecting Europe and China, which started operations between 2011 and 2015. The countries' trade patterns with railway connections to China are then compared to the countries without railway connections to China. We find the intercontinental railways have a positive effect on China's exports to its trading partners in Central Asia and Europe, especially concerning exports of manufactured goods, machinery and transport equipment, and miscellaneous manufactured articles. Moreover, the intercontinental railways have a positive effect on China's imports of food and live animals from its trading partners.
\end{abstract}

\section{Keywords}

One Belt, One Road; Trade; Transportation cost

\section{JEL Code}

F02, F14, R4 


\section{INTRODUCTION ${ }^{1}$}

In autumn 2013, Chinese President Xi Jinping successively proposed the "Silk Road Economic Belt" and the "21st Century Maritime Silk Road" initiatives that are collectively known as the "One Belt, One Road" Initiative (hereafter referred to as the "OBOR"). In 2015, with the release of the "Vision and Actions on Jointly Building 'One Belt, One Road'" (hereafter referred to as the "Vision and Actions"), the creation of the Asian Infrastructure Investment Bank (AIIB), and the establishment of the Silk Road Fund, the "One Belt, One Road" Initiative has moved on to the stage of implementation. Europe plays an important role in the OBOR initiative. As stated in the "Vision and Actions", the OBOR initiative focuses on "connecting the vibrant East Asia economic circle at one end and the developed European economic circle at the other end", as an attempt to revive the historical Eurasian "Silk Roads." In particular, the "belt" is a land route designed to connect China with Central Asia, Eastern and Western Europe. Note that the meaning of connectivity is all dimensional and multi-tiered, including policy, facility, trade, finance and culture (NDRC 2015). An important component is to construct international railway transport connections and establish new industrial clustering areas along them.

Policy analyses and debates have focused on the OBOR initiative since its introduction. It em-

1 We would like to thank Jing Li, Hans-Jörg Schmerer, Yun-wing Sung, Markus Taube, Yifan Zhang, the participants at the First International Joint Seminar on the New Silk Road and Sino-European Cooperation, the Shanghai-Hong Kong Development Institute 2015 Annual Conference, the First Silk Road Dialogue and 2016 Annual Conference of the Silk Road Think Tank Association, and a seminar at Nanjing University of Science and Technology for helpful comments and discussions. Special thanks to Tobias Fausten, Wenyang Luo, Jiajia Ma, and Hui Zhu for their contributions to this project, and to the Duisburger Hafen AG and the Chongqing Social Science Academy that allowed us to conduct interviews. All errors, of course, remain our own. bodies China's new opening-up strategies developed in response to the altered domestic and international circumstances (Lin 2015). If all the OBOR initiative's goals are realized, it will significantly affect China and Europe and will become a propeller for hinterland development. The extent of its potential effect and influence on trade between China and Europe are still pending for answers. In this paper, we focus on the nine Chinese-European trains that are already in operation, and conduct a pilot study on the effect of these Silk Road railways on the trade between China and its trading partners in Central Asia and Europe. Of course, the OBOR initiative is a very recent development and most of the big projects still have not been carried out. Besides, for the nine railway lines under study, the earliest one started to operate in 2011, the latest one started to operate in 2015, and each line evolves very quickly. It is still too early to draw a conclusion regarding the OBOR initiative's impacts at this stage, but a systematic study of the nine Chinese-European trains may serve as a starting point in order to evaluate the OBOR initiative's potential effect on trade between China and Europe.

Although using railroads to move goods from one place to another is one of the oldest forms of modern trade, the idea and scope behind the New Silk Road railways are totally new and the potential is huge. In the era of the Internet and globalization, linking continents by intercontinental railways might give birth to a real transportation revolution. This is because, compared to ocean shipping, the intercontinental railways have significantly reduced the time needed; compared to air shipping, the intercontinental railways have significantly reduced the transportation costs by 40 percent; $^{2}$ and, compared to road networks,

2 Yuxinou Railway serves as the example. The data is from the Hong Kong Trade Development Council report (The Hong Kong Trade Development Council 2015). 
railway networks are 50 percent more productive in promoting international trade (Egger \& Larch 2004). Moreover, the investment and improvement of transportation infrastructure can function as a driver for productivity and economic growth as well as prosperity and poverty reduction for the countries and regions along the "Silk Road Economic Belt". Note that earlier studies have found that trade infrastructure is related to development, because it improves the external trade balance (Celbiș et al. 2014), reduces income inequality and poverty (Calderón \& Servén 2004; Seneviratne \& Sun 2013), and enhances economic growth (Brooks 2009).

Nonetheless, thus far, there is a clear gap in the literature with regard to research on the relationship between railway infrastructure and trade. Most research on the relationship between infrastructure and trade has primarily focused on the roles played by road and port infrastructure (Nordas \& Piermartini 2004; Hummels 2007). Although there are some econometric studies researching the effects of railways on trade, these focus primarily on country-specific developments and do not review the effect of railway infrastructure connecting various different countries and regions on trade (Donaldson 2012; Donaldson and Hornbeck 2013). This gap is largely due to the earlier absence of such cross-country large-scale projects. The identification of this clear gap in the infrastructure/ trade literature propels us to use the OBOR initiative as a means to investigate the further implications of railway infrastructure for trade.
By utilizing the gravity model, we compare the trade patterns of the countries along the railways to the countries that have no railway connections to China. We find the New Silk Road railways facilitate bilateral trade between China and countries along the railway lines. Railway connection has a positive effect on China's exports to its trading partners in Central Asia and Europe, especially the export of manufactured goods, machinery and transport equipment, and miscellaneous manufactured articles. Moreover, railway connection has a positive effect on China's imports of food and live animals from its trading partners, although the effect on the total imports is not significant. In this regard, our finding echoes Celbiş's et al. (2014) conclusion that infrastructure has a slightly larger impact on exports than on imports, and supports Egger and Larch's (2004) results on the effects of railway networks on promoting international trade.

The remainder of this article is organized as follows. Section 2 will provide overviews on the railway networks and the history and trend of trade between Europe and China. Section 3 will explain the theoretical approach and the empirical model. Section 4 elaborates in further detail upon the independent and dependent variables and the data. Section 5 contains the multiple regression analysis, revealing several patterns in trade between China and the selected countries. Section 6 illustrates our findings by using a case study on the "Chongqing-Xinjiang-Duisburg" cargo rail route (known as the "Yuxinou" railway). The final section illustrates our conclusions.

\section{AN INTRODUCTION OF RAILWAY CONNECTIONS AND SINO-EU TRADE}

\subsection{PATTERNS OF RAILWAY CONNEC- TIONS BETWEEN THE INVOLVED COUNTRIES}

From 2011 to 2015, many new railway lines (presently nine in total) that directly connect Chi- na to Europe started to operate. The first one, Yuxinou, started operating in 2011, and serves as a case study toward the end of this paper in Section 6. The railway lines connect many Asian and European countries with China. Poland, the Czech Republic, Germany, Spain, Russia, and Uz- 
bekistan serve as the final destinations of these railway lines.

Yuxinou, the pioneer among the new direct railway connections between Europe and China, sets out from Chongqing and reaches its final destination in Duisburg. As Chongqing is the largest production base of laptop computers in the world, these items usually account for almost half of the cargo (Deng 2015). In addition, Yuxinou operates according to a fixed timetable, which makes it more convenient for firms to ship their products.

Hanxinou starts from Wuhan, and at the end reaches the Czech Republic. In addition to Foxconn products, it is also responsible for transporting cars and building materials. In addition, Hanxinou started to transport some cargo when it returns to China from Europe. Once every two weeks Hanxinou takes automobile parts back to China (Xinhuanet 2014).

Suzhou is the beginning point of the Sumanou Railway, which passes through Russia, Belarus, and finally arrives in Warsaw, Poland. Following its first operation in November 2012, the distance was listed in the Guinness World Records as the longest transportation distance of container railways (He 2012). Before Sumanou, there was no direct railway connection with Europe in Southeastern China. The cargo of the train mainly contains products made in Suzhou including electronic products, machinery, clothing and household items etc.

The Rongou Railway also reaches Poland, but originates in Chengdu. Since April 2013, Rongou's speed continues increasing. At the beginning, the transportation time was about 14 days but now it only takes about 10 and a half days. The highlight of Rongou is that it operates with a fixed time schedule. Many other trains between Europe and China actually have no fixed running time. Railway operators typically wait until the trains are filled up before setting off for the final destinations. Rongou, however, runs every Satur- day. Export companies welcome the fixed schedule, as it enhances the convenience for them to arrange production activities (Yang 2015). As for the cargo, Rongou mostly transports electronic products, machinery, auto parts, and clothing.

The Zhengou Railway starts from Zhengzhou and reaches its final destination in Hamburg. With this railway, Chinese products in Henan Province will not need to be first transported to Qingdao and then by sea. Instead, they can be shipped directly to Europe.

Hexinou starts from Hefei and began to operate in June 2014. However, at that time it only transported products to Kazakhstan. Later, Hexinou's operations extended to Russia and in June 2015 reached Germany in Hamburg. From Hefei to Hamburg it takes about 15 days and the distance is about $11,000 \mathrm{~km}$. Cargoes mainly include electronic and household appliances, textiles etc. (Yin 2015).

Xiangou's shipments began in October 2014. Currently Xiangou transports items through three routes. One starts in Changsha, continues through Kazakhstan, Russia, Belarus, and Poland before arriving in Duisburg, Germany. The other two routes end in Moscow, Russia and Tashkent, Uzbekistan. Tea, porcelain, and automobile parts are examples of the types of products currently transported on the Xiangou rail line (Zhang 2014).

In November 2014, Yixinou started operations from Yiwu to Spain. Yixinou has by far the longest transportation distance among all these railways between Europe and China. As Yiwu is a city famous for its small commodities, the train usually carries miscellaneous goods to Spain. It transports Spanish products, including wine, olive oil, and cured ham back to China as well (Liu 2015). As the train only started operating in late 2014, the newly connected countries of the Ukraine, France and Spain are not considered in the present study. They should, however, form part of future research on the OBOR initiative. 
Haou, the most recently incorporated railway line connecting China with Europe, began operations in June 2015. It runs from Harbin and reaches its final destination in Hamburg. The first shipments included clothing, electronic components, and automobile parts. Currently product shipments from Harbin originate from
Japan, South Korea, and northern China. As the transportation time through $\mathrm{Haou}$ is 15 days, it is quite convenient for companies to ship their products through this railway because it diminishes the transportation time by 50 percent (Egorova 2015). Table 1 gives a summary of all the nine rail ways.

\section{Table 1: China-EU Railway Lines}

$\begin{array}{llcccc} & \text { Route } & \text { Distance } & \text { Duration } & \text { Start } & \text { Frequency } \\ \text { Yuxinou } & \text { Chongqing-Duisburg } & 11,179 \mathrm{~km} & 16 \text { days } & \text { July } 2011 & 3 / \text { week } \\ \text { Hanxinou } & \text { Wuhan-Mělník (CZ)/Pardubice (CZ)/ } & 10,863 \mathrm{~km} & 16 \text { days } & \text { Oct. } 2012 & 2 \text {-3/ week } \\ & \text { Turkmenistan } & & & & \\ \text { Sumanou } & \text { Suzhou-Warsaw } & 11,200 \mathrm{~km} & 18 \text { days } & \text { Nov. } 2012 & 6-8 / \text { week } \\ \text { Rongou } & \text { Chengdu-Łódź } & 9,826 \mathrm{~km} & 10.5 \text { days } & \text { April } 2013 & 1 / \text { week } \\ \text { Zhengou } & \text { Zhengzhou-Hamburg } & 10,214 \mathrm{~km} & 19-20 \text { days } & \text { July } 2013 & 1 / \text { week } \\ \text { Yixinou } & \text { Yiwu-Madrid } & 13,052 \mathrm{~km} & 21 \text { days } & \text { Nov. } 2014 & 3 \times \text { until now } \\ \text { Hexinou } & \text { Hefei-Germany } & 11,000 \mathrm{~km} & 15 \text { days } & \text { June } 2014 & 2 / \text { month } \\ \text { Xiangou } & \text { Changsha-Duisburg/Moscow/Tashkent } & 11,808 \mathrm{~km} & 18 \text { days } & \text { Oct. } 2014 & \text { Every } 10 \text { days } \\ \text { Haou } & \text { Harbin-Hamburg } & 9,820 \mathrm{~km} & 15 \text { days } & \text { June } 2015 & 1 / \text { week }\end{array}$

The data for the China-EU railway lines was collected in August 2015

\subsection{CHINA-EU TRADE}

Although this paper focuses on China's trade with not only the EU-25 countries, but also its trade with Belarus, Russia and Kazakhstan, the EU as an entity is becoming an increasingly significant trading partner of China. The rail networks connecting China with Europe are enhancing their trade relations. In recent years, Chinese and European diplomatic and trade relations have quickly progressed, demonstrating a greater need for faster, cheaper and more effective trade routes compared to the maritime shipping options primarily in use today. Today China is the EU's second largest trading partner, behind the United States (The European Commission 2015), and since 2004, the EU has remained China's largest trading partner (Xin 2013). Between 2003 and 2012, the trade volume between China and the EU quadrupled from 125.22 billion USD to 546.04 billion USD (ibid.). As an entity, the EU itself conducts significant amounts of trade with China.

Figure 1 demonstrates that for almost all $25 \mathrm{EU}$ countries, compared to 2005, imports strongly increased from China by the year 2014. Compared to the total imports from China for all EU-25 countries of $\$ 442$ billion, China's top six EU trading partners generated three quarters of import revenues.

Figure 2 reveals that EU exports to China increased by a significantly large amount in 2014 as compared to 2005. Concerning China's imports from the EU-25 countries, its top six trading partners in 2014 were Germany, Belgium, the United Kingdom, The Netherlands, France, and Italy. Their total exports to China, which amounted to $\$ 181$ billion in 2014, constituted about 55 percent of total EU exports to China, which equalled $\$ 214$ billion.

Figure 3 shows that there are clear rising trends of the imports from China for Germany, Poland and the Czech Republic, which are the EU countries that have been connected by rail. Although it cannot be concluded directly from these graphs that the recent increase in imports is due to the New Silk Road railways, they can be used as a reference for the general development of Sino-EU trade. 
Figure 1: EU-25 countries' imports from China

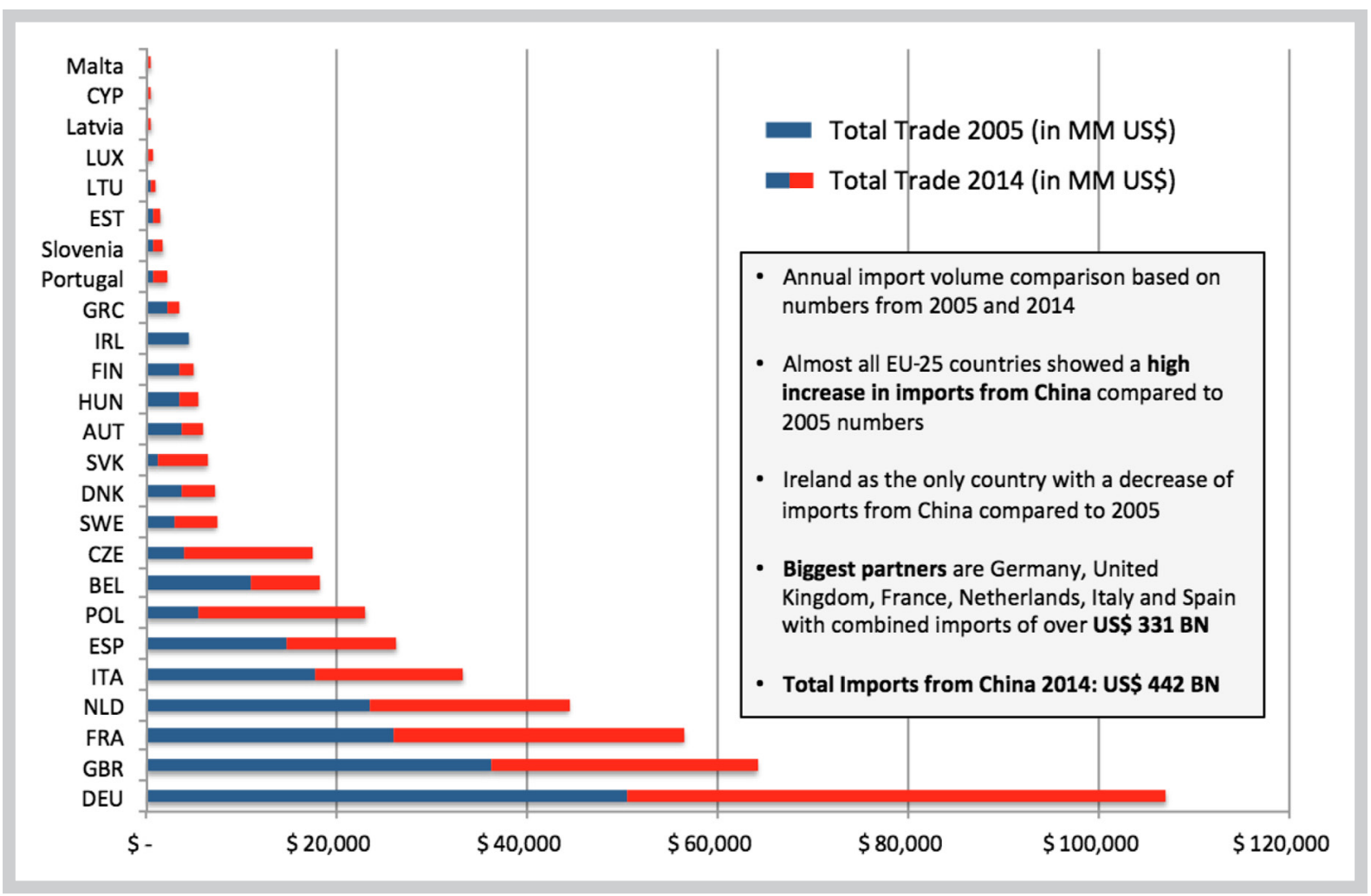

Data source: WITS database

Figure 2: EU-25 countries' exports to China

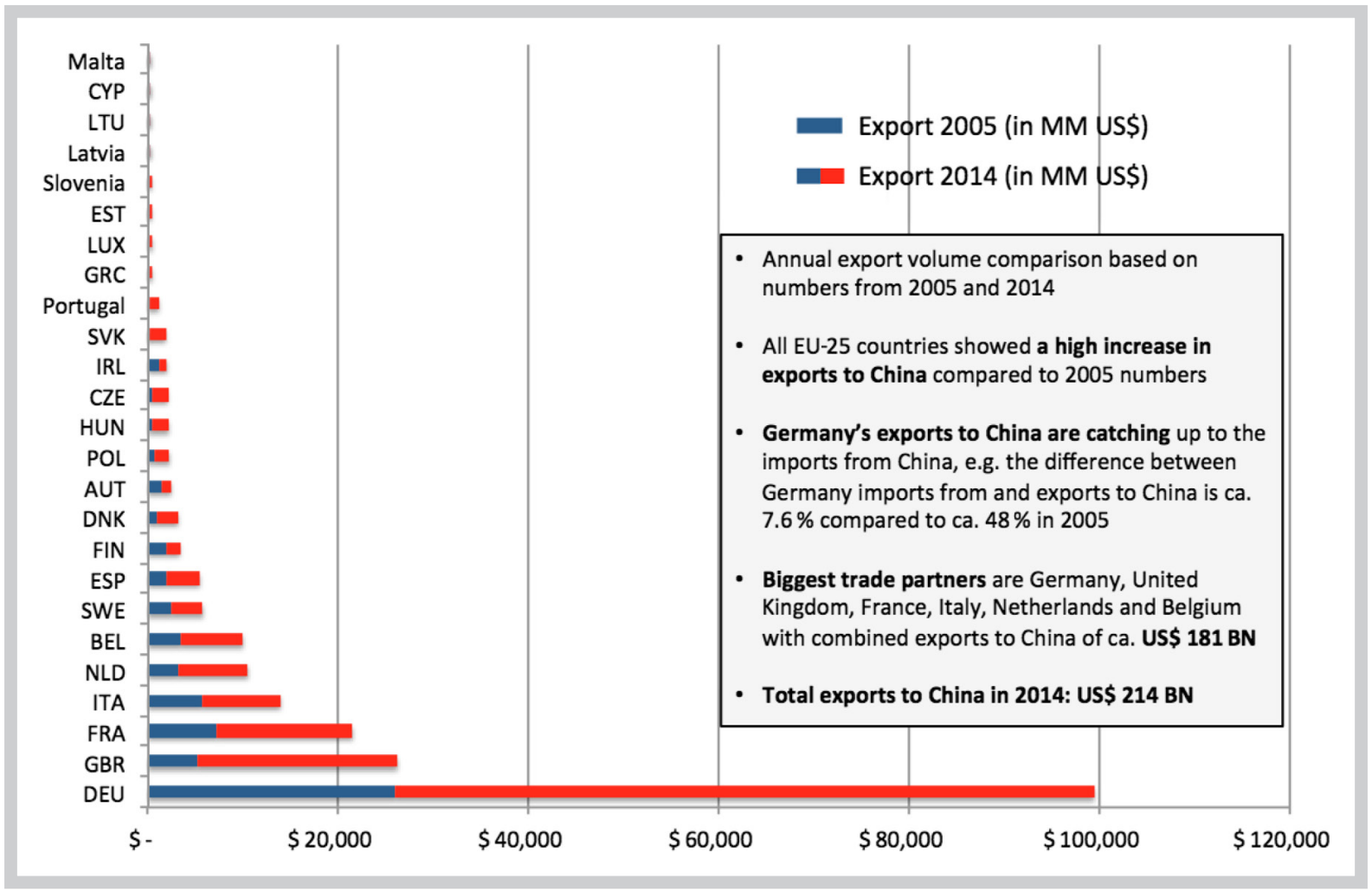

Data source: WITS database 


\section{Figure 3: Development of imports from China to Germany, the Czech Republic and Poland}

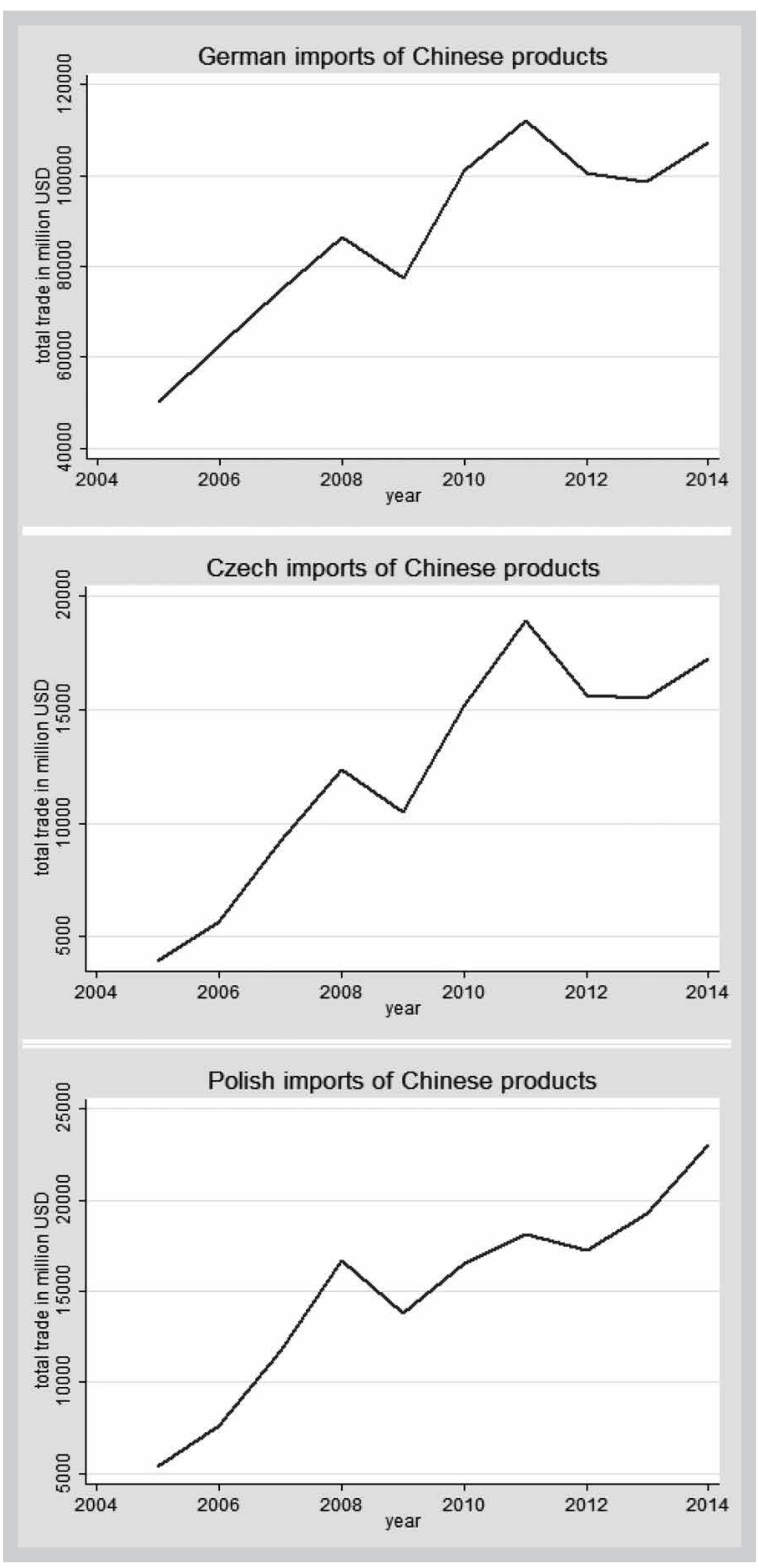

Data source: WITS database

\section{THE EMPIRICAL MODEL}

One of the most critically acclaimed approaches to the study of trade relations is the gravity model. Since the 1960s, it has become a popular instrument in empirical foreign trade analysis (Kepaptsoglou et al. 2010). The model stresses that trade increases with the size and proximity of the trading partners (Porojan 2001).
The basic form of the gravity model for two economies labelled $i$ and $j$ can be described by the following equation:

$$
T_{i j}=H \frac{Y_{i} Y_{j}}{d_{i j}^{2}}
$$

According to the gravity model, exports from country $i$ to country $j$ are explained by their economic sizes $\left(Y_{i}\right.$ and $\left.Y_{j}\right)$, their direct geographical distances and a set of other variables, such as tariffs and geography (all these can be captured by $d_{i j}$ ).

For example, whether or not the country has a connection to the sea is considered to be one significant variable. Therefore, economic size and the geographical distance between countries are especially highlighted. Studies have revealed that the distance is particularly important: roughly one quarter of world trade by value occurs between countries that share a land border and half of world trade occurs between partners less than 3000 kilometres apart (Berthelon \& Freund 2004). Until quite recently, for trade with distant partners, nearly all merchandise trade moved via ocean and air modes (Hummels 2007).This also points to the innovation and creativity behind the New Silk Road by rail, because it is completely new in its integrated approach to connect China and Europe through railway networks. The gravity model's insights - especially its assumption that projects like the OBOR project may increase the flow of goods through the reduction of transport costs - are useful for our project.

The following empirical model is used to estimate the effect of the new Silk Road intercontinental railways on trade between China and its partners.

$$
y_{i t}=\beta \text { railcon }_{i t}+\gamma X_{i t}+\varepsilon_{i t}
$$

In equation (2), $y_{i t}$ is the dependent variable, which includes import and export data of China and various other countries. The main explanatory variable on the right hand side, railcon $n_{t}$, is defined as a dummy variable indicating the status of rail connection to China. We also include 
a set of control variables: $X_{i t}$, which can affect trade with China. The control variables include: the weighted tariff average, distance, landlocked, GDP and official exchange rate.

Moreover, $\beta$ is the coefficient of railway connection; it should have a positive sign if the hypothesis holds. The main hypotheses are as follows:
Hypothesis 1:

Railway connection will increase the connected country's imports from China.

Hypothesis 2:

Railway connection will increase the connected country's exports to China.

\section{DATA COLLECTION AND ANALYSIS}

We collected a panel data with 28 countries from the years 2005 to 2014 in order to observe the growth or decline of trade volumes in this tenyear time span. This allows us to discern a reasonable time frame before and after the railway connections started operations.

The number of EU countries in this study was narrowed down to 25 instead of all the 28 members. Croatia, Bulgaria and Romania are excluded because these three countries joined the EU after 2007. In the meantime, three non-EU countries (Belarus, Kazakhstan and the Russian Federation) were added to our dataset. From the nine railways we observed, all of them have a connection with Belarus and the Russian Federation, and six of them have a connection with Kazakhstan. Belarus, Kazakhstan and the Russian Federation serve as important passing stations on the railway lines. We think the 'One Belt, One Road' project will have a large impact on these three countries' economies and trade as well.

The trade volume data are subdivided into the ten SITC categories. We chose the SITC Revision 3 nomenclature because in the WITS databank, the latest revision of SITC Revision 4 is only available for a very limited number of years. In order to achieve uniformity in our dataset, we collected the data of trade flows listed by SITC Revision 3.

This trade data was collected for exports (from various countries to China) and imports (from
China to various other countries). Gross exports and imports were collected from the WITS dataset, because they include both net exports and re-imports in the export data, and net-imports and re-exports in the import data. In short, the gross figures cover the whole movement of goods, without subtracting re-exports or re-imports from the raw figures. As the effect of the railways on the movement of goods across borders is the object of the present study, gross exports and imports are chosen as the main dependent variables.

The weighted tariff average can reflect the average tariff numeric more realistically than the simple average tariff. The simple tariff average merely calculates the sum of all tariff rates divided by the quantity of the rates. This regulation mixes all the products together and ignores the difference that some products are less or much more imported or exported than others. The weighted tariff average, however, measures the differences in imports and exports.

Google Maps was utilized to measure the direct distance between the 28 countries' capitals and Beijing. Landlocked countries are assigned a "1" (no access to the sea) and " 0 " represents the countries not landlocked. With Google Maps, it is possible to observe whether a country is landlocked or not. We decided to collect this data because the geography of a country may have a large impact on its international trade. The Caspian Sea was judged to not have an influence on 
international trade, which is why Kazakhstan is recorded as landlocked.

As for the railway connection, we use "1" to represent the existence of a railway connection between China and the partner country for a certain year. Before the year in which the railway started operation, "0" represents the absence of a railway connection. For example, in the case of Germany we have "0" for 6 years (from 2005 to 2010) and "1" for 4 years (from 2011 to 2014).

GDP data was collected for China and for all the other countries included in the study. It was collected from the IMF World Economic Outlook database. Official exchange rate data was collected from the World Bank. The official exchange rate as Chinese Yuan to US Dollar and Chinese Yuan to Euro is maintained. If the exchange rate of Chinese Yuan to US Dollar or Chinese Yuan to Euro increases, it means that 1 Yuan can buy less of the other currency, corresponding to a depreciation of the Yuan. We hypothesize that a depreciation of the Yuan may have a positive effect on Chinese exports, as the prices for commodities in Yuan are falling for foreign buyers, who change Euros or Dollars to Yuan. Similarly, an appreciation of the Yuan may have a negative effect on Chinese exports.

Although we attempted to collect data as intact as possible, some data still contained missing values, such as in the weighted tariff averages.
In the export data, missing values occurred for small countries, which export very insignificant quantities of the respective categories to China in some years and probably close to nothing in other years. In this case we assume that the missing values are actually equal to zero and changed the data accordingly. In the import data, the missing value for Finland, SITC 9 for 2011, was replaced by the average of the values from 2010 and 2012. This is because the values around the year 2011 suggest that the value cannot be expected to be equal to zero. The average of the year before and after the missing value provides an educated guess as to the real trade volume for 2011. Regarding the rest of the import data, the assumption that missing values are equal to zero was found to be accurate. The observation of Russian imports and exports in the year 2014 was excluded from the analysis altogether, as all trade figures are missing. Missing tariff values in the export data were replaced by the average of all available tariff values for the respective exporting country. Unlike the tariffs imposed by the Chinese side, the tariffs imposed by the other countries against Chinese products show a clear downward trend over time. Therefore, the missing tariff values in the import data were replaced by the tariff value of the year before, assuming that the tariff in year $t$ is closely related to the tariff in year $t-1$. The total trade volume per country and year was computed by summing the values of all 10 SITC categories.

\section{RESULtS}

In this section, the results of the regression analysis are presented. Coefficients at a significance level of $p=0.01$ are considered to be significant effects. The regression analysis is performed first on the export data (exports from various countries to China) and then on the import data (imports from China to various countries). All regression analyses presented here include the country dummy and the year dummy, which serves to control for country-specific and year-specific effects. We also take into account the data clusters when estimating the standard errors.

In the first regression test, the effect of the predictor variables on the log transformation of the total exports was investigated. Strikingly, whether the respective country has a rail connection to China or not had no significant effect on the de- 
pendent variable. According to our expectations, significant negative effects on exports were observed for distance, the landlocked variable and the Yuan to Dollar exchange rate. Though the hypothesis that the rail connection has a significant effect on exports cannot be verified here, the high $R$ value $\left(R^{2}=0.98\right)$ demonstrates that the regression model used here has a high predictive validity (see Table 2 ).

In a further regression analysis of the export of all individual SITC categories, a positive significant effect was found only for category 0 (food and animals). Here, the exports increased on average by 100.6 percent for the countries that are connected by rail (see Table 3 ). This effect is very large and is given further attention in the discussion section.

Next, a regression model to investigate the effects on the log transformation of total imports

Table 2: Regression on logtrade (exports)

\begin{tabular}{lcc} 
Predictor & $\begin{array}{c}\text { logtrade (export) } \\
\text { No year }\end{array}$ & $\begin{array}{c}\text { logtrade (export) } \\
\text { /w year }\end{array}$ \\
Railway & 0.043 & 0.064 \\
connection & $(0.138)$ & $(0.144)$ \\
Tariff & 0.003 & 0.000 \\
& $(0.051)$ & $(0.050)$ \\
\hline Distance & -0.000 & -0.000 \\
& $(0.000)^{* *}$ & $(0.000)^{* *}$ \\
Exchange rate & -0.314 & -0.164 \\
(Yuan-USD) & $(0.108)^{* *}$ & $(0.098)$ \\
\hline Exchange rate & -0.019 & 0.004 \\
(Yuan-Euro) & $(0.051)$ & $(0.049)$ \\
Landlocked & -1.563 & -1.588 \\
& $(0.292)^{* *}$ & $(0.297)^{* *}$ \\
GDP & 0.000 & 0.000 \\
& $(0.000)$ & $(0.000)$ \\
\hline Chinese GDP & 0.000 & -0.000 \\
& $(0.000)$ & $(0.000)$ \\
Constant & 13.521 & -291.104 \\
& $(1.293)^{* *}$ & $(137.653)^{*}$ \\
Year dummy & No & Yes \\
Country dummy & Yes & Yes \\
\hline$R^{2}$ & 0.98 & 0.98 \\
N & 279 & 279 \\
\hline
\end{tabular}

Robust standard errors controlling for clusters in parentheses; ${ }^{*} p<0.05 ;{ }^{* *} p<0.01$ from China was conducted. In this case, the rail connection variable was found to have a significant positive effect. The coefficient observed is 0.279 . This means that a country which is connected to China by one of the OBOR railways imports on average 27.9 percent more commodities from China than a country which is not connected (see Table 4). Significant negative coefficients were observed for the Yuan to Dollar exchange rate and the landlocked variable. An additional significant positive effect was observed for the Yuan to Dollar exchange rate. Contrary to our expectations, slightly positive and significant effects were observed for the tariff and distance variables.

The significant results for the total import data warrant a further analysis of import figures of selected SITC categories. Categories for which the trade by train between China and the other countries can be expected to be especially

\section{Table 3: Regression on log SITC 0 (exports)}

\begin{tabular}{|c|c|c|}
\hline Predictor & $\begin{array}{c}\text { logsitc0 (exports) } \\
\text { No Year }\end{array}$ & $\begin{array}{c}\text { logsitc0 (exports) } \\
\text { /w Year }\end{array}$ \\
\hline $\begin{array}{l}\text { Railway } \\
\text { connection }\end{array}$ & $\begin{array}{l}1.006 \\
(0.366)^{*}\end{array}$ & $\begin{array}{l}1.031 \\
(0.387)^{*}\end{array}$ \\
\hline Tariff & $\begin{array}{l}-0.029 \\
(0.095)\end{array}$ & $\begin{array}{l}-0.031 \\
(0.097)\end{array}$ \\
\hline Distance & $\begin{array}{l}0.000 \\
(0.000)^{* *}\end{array}$ & $\begin{array}{l}0.000 \\
(0.000)^{* *}\end{array}$ \\
\hline $\begin{array}{l}\text { Exchange rate } \\
\text { (Yuan-USD) }\end{array}$ & $\begin{array}{c}0.249 \\
(0.218)\end{array}$ & $\begin{array}{c}0.393 \\
(0.405)\end{array}$ \\
\hline $\begin{array}{l}\text { Exchange rate } \\
\text { (Yuan-Euro) }\end{array}$ & $\begin{array}{c}0.257 \\
(0.310)\end{array}$ & $\begin{array}{c}0.278 \\
(0.279)\end{array}$ \\
\hline Landlocked & $\begin{array}{l}-4.738 \\
(0.860)^{* *}\end{array}$ & $\begin{array}{l}-4.768 \\
(0.850)^{* *}\end{array}$ \\
\hline GDP & $\begin{array}{l}-0.000 \\
(0.000)\end{array}$ & $\begin{array}{l}-0.000 \\
(0.000)\end{array}$ \\
\hline Chinese GDP & $\begin{array}{l}0.000 \\
(0.000)^{* *}\end{array}$ & $\begin{array}{c}0.000 \\
(0.000)\end{array}$ \\
\hline Constant & $\begin{array}{l}-2.477 \\
(4.034)\end{array}$ & $\begin{array}{l}-299.269 \\
(679.289)\end{array}$ \\
\hline Year dummy & No & Yes \\
\hline Country dummy & Yes & Yes \\
\hline$R^{2}$ & 0.91 & 0.91 \\
\hline$N$ & 270 & 270 \\
\hline
\end{tabular}

Robust standard errors controlling for clusters in parentheses; ${ }^{*} p<0.05 ;{ }^{* *} p<0.01$ 
Table 4:

\section{Regression on logtrade (imports)}

\begin{tabular}{|c|c|c|}
\hline Predictor & $\begin{array}{c}\text { logtrade (imports) } \\
\text { No year }\end{array}$ & $\begin{array}{c}\text { logtrade (imports) } \\
\text { / w year }\end{array}$ \\
\hline $\begin{array}{l}\text { Railway } \\
\text { connection }\end{array}$ & $\begin{array}{l}0.279 \\
(0.064)^{* *}\end{array}$ & $\begin{array}{l}0.291 \\
(0.065)^{* *}\end{array}$ \\
\hline Tariff & $\begin{array}{l}0.086 \\
(0.010)^{* *}\end{array}$ & $\begin{array}{l}0.081 \\
(0.012)^{* *}\end{array}$ \\
\hline Distance & $\begin{array}{l}0.000 \\
(0.000)^{* *}\end{array}$ & $\begin{array}{l}0.000 \\
(0.000)^{* *}\end{array}$ \\
\hline $\begin{array}{l}\text { Exchange rate } \\
\text { (Yuan-USD) }\end{array}$ & $\begin{array}{l}-0.604 \\
(0.071)^{* *}\end{array}$ & $\begin{array}{l}-0.549 \\
(0.063)^{* *}\end{array}$ \\
\hline $\begin{array}{l}\text { Exchange rate } \\
\text { (Yuan-Euro) }\end{array}$ & $\begin{array}{l}0.230 \\
(0.040)^{* *}\end{array}$ & $\begin{array}{l}0.234 \\
(0.039)^{* *}\end{array}$ \\
\hline Landlocked & $\begin{array}{c}-0.978 \\
(0.453)^{*}\end{array}$ & $\begin{array}{c}-1.022 \\
(0.445)^{*}\end{array}$ \\
\hline GDP & $\begin{array}{c}0.000 \\
(0.000)\end{array}$ & $\begin{array}{c}0.000 \\
(0.000)\end{array}$ \\
\hline Chinese GDP & $\begin{array}{c}0.000 \\
(0.000)\end{array}$ & $\begin{array}{c}-0.000 \\
(0.000)\end{array}$ \\
\hline Constant & $\begin{array}{l}9.847 \\
(1.040)^{* *}\end{array}$ & $\begin{array}{c}-95.173 \\
(100.353)\end{array}$ \\
\hline Year dummy & No & Yes \\
\hline Country dummy & Yes & Yes \\
\hline$R^{2}$ & 0.98 & 0.98 \\
\hline$N$ & 279 & 279 \\
\hline
\end{tabular}

Robust standard errors controlling for clusters in parentheses; * $p<0.05 ;{ }^{* *} p<0.01$

significant are SITC 5 (chemicals and related products), SITC 6 (manufactured goods) and SITC 7 (machinery and transport equipment). Category 7 also covers electrical appliances such as laptops, which are partly transported from Chinese production hubs such as Chongqing to European markets via the new OBOR train routes.

No significant effect of the rail connection was found for category 5 (see Table 5). Imports of Chinese chemicals and related products do not seem to be significantly influenced by the existence of the railways considered here. However, for categories 6 and 7, the effect of rail connection was significant and positive. The import of Chinese manufactured goods was on average 25.4 percent larger for countries with an OBOR train connection and the import of Chinese machinery and transport equipment was on aver-
Table 5: Regression on the imports of selected SITC categories (SITC 5 machinery and transport equipment including electrical appliances like

\begin{tabular}{|c|c|c|}
\hline Predictor & $\begin{array}{c}\text { logsitc5 (imports) } \\
\text { No year }\end{array}$ & $\begin{array}{c}\text { logsitc6 (imports) } \\
\text { No year }\end{array}$ \\
\hline Railway connection & $\begin{array}{c}0.027 \\
(0.059)\end{array}$ & $\begin{array}{l}0.254 \\
(0.094)^{* *}\end{array}$ \\
\hline Tariff & $\begin{array}{l}0.061 \\
(0.011)^{* *}\end{array}$ & $\begin{array}{l}0.095 \\
(0.013)^{* *}\end{array}$ \\
\hline Distance & $\begin{array}{c}0.000 \\
(0.000)\end{array}$ & $\begin{array}{l}-0.000 \\
(0.000)^{* *}\end{array}$ \\
\hline Exchange rate (Yuan-USD) & $\begin{array}{l}-0.478 \\
(0.068)^{* *}\end{array}$ & $\begin{array}{l}-0.582 \\
(0.072)^{* *}\end{array}$ \\
\hline Exchange rate (Yuan-Euro) & $\begin{array}{l}0.193 \\
(0.036)^{* *}\end{array}$ & $\begin{array}{l}0.422 \\
(0.056)^{* *}\end{array}$ \\
\hline Landlocked & $\begin{array}{l}-1.301 \\
(0.354)^{* *}\end{array}$ & $\begin{array}{l}-0.660 \\
(0.429)\end{array}$ \\
\hline GDP & $\begin{array}{c}0.000 \\
(0.000)\end{array}$ & $\begin{array}{c}0.000 \\
(0.000)\end{array}$ \\
\hline Chinese GDP & $\begin{array}{l}0.000 \\
(0.000)^{* *}\end{array}$ & $\begin{array}{c}0.000 \\
(0.000)\end{array}$ \\
\hline Constant & $\begin{array}{l}7.402 \\
(0.855)^{* *}\end{array}$ & $\begin{array}{l}6.789 \\
(1.136)^{* *}\end{array}$ \\
\hline Year dummy & No & No \\
\hline Country dummy & Yes & Yes \\
\hline$R^{2}$ & 0.99 & 0.98 \\
\hline N & 279 & 279 \\
\hline
\end{tabular}

Robust standard errors controlling for clusters in parentheses; ${ }^{*} p<0.05 ;{ }^{* *} p<$

age 27.9 percent larger for countries with an OBOR train connection. Contrary to our expectations, the effects observed here are not larger than the effect of rail connection on the overall imports (see above). Therefore, we cannot say that the goods in categories 6 and 7 play a special role in the transport of goods by OBOR trains. Their imports to countries connected by train expands by about the same proportion as general imports.

In a further test of the other SITC categories, the imports of category 8 (miscellaneous manufactured articles) were found to benefit the most from the railway connection. A highly significant coefficient of railway connection $=0.359$ was found (see Table 6). This means that the imports of category 8 from China can be expected to expand on average by 35.9 percent for countries, which are connected by railway. 


\section{chemicals and related products; SITC 6: manufactured goods; SITC 7: laptops)}

logsitc7 (imports) logsitc5 (imports) logsitc6 (imports) logsitc7 (imports)

\begin{tabular}{|c|c|c|c|}
\hline No year & I w year & I w year & I w year \\
\hline $\begin{array}{l}0.279 \\
(0.079)^{* *}\end{array}$ & $\begin{array}{c}0.021 \\
(0.061)\end{array}$ & $\begin{array}{c}0.265 \\
(0.094)^{* *}\end{array}$ & $\begin{array}{l}0.292 \\
(0.080)^{* *}\end{array}$ \\
\hline $\begin{array}{l}0.082 \\
(0.018)^{* *}\end{array}$ & $\begin{array}{c}0.064 \\
(0.013)^{* *}\end{array}$ & $\begin{array}{l}0.089 \\
(0.014)^{* *}\end{array}$ & $\begin{array}{c}0.076 \\
(0.018)^{* *}\end{array}$ \\
\hline $\begin{array}{l}0.000 \\
(0.000)^{* *}\end{array}$ & $\begin{array}{c}0.000 \\
(0.000)\end{array}$ & $\begin{array}{c}-0.000 \\
(0.000)\end{array}$ & $\begin{array}{l}0.000 \\
(0.000)^{* *}\end{array}$ \\
\hline $\begin{array}{l}-0.624 \\
(0.104)^{* *}\end{array}$ & $\begin{array}{l}-0.507 \\
(0.068)^{* *}\end{array}$ & $\begin{array}{l}-0.529 \\
(0.099)^{* *}\end{array}$ & $\begin{array}{l}-0.562 \\
(0.083)^{* *}\end{array}$ \\
\hline $\begin{array}{c}0.161 \\
(0.052)^{* *}\end{array}$ & $\begin{array}{l}0.191 \\
(0.038)^{* *}\end{array}$ & $\begin{array}{c}0.426 \\
(0.057)^{* *}\end{array}$ & $\begin{array}{c}0.166 \\
(0.051)^{* *}\end{array}$ \\
\hline $\begin{array}{c}-1.119 \\
(0.504)^{*}\end{array}$ & $\begin{array}{l}-1.277 \\
(0.341)^{* *}\end{array}$ & $\begin{array}{c}-0.702 \\
(0.407)\end{array}$ & $\begin{array}{c}-1.169 \\
(0.504)^{*}\end{array}$ \\
\hline $\begin{array}{c}0.000 \\
(0.000)\end{array}$ & $\begin{array}{c}0.000 \\
(0.000)\end{array}$ & $\begin{array}{c}0.000 \\
(0.000)\end{array}$ & $\begin{array}{c}0.000 \\
(0.000)\end{array}$ \\
\hline $\begin{array}{c}-0.000 \\
(0.000)\end{array}$ & $\begin{array}{c}0.000 \\
(0.000)^{*}\end{array}$ & $\begin{array}{c}0.000 \\
(0.000)\end{array}$ & $\begin{array}{c}-0.000 \\
(0.000)\end{array}$ \\
\hline $\begin{array}{l}10.219 \\
(1.506)^{* *}\end{array}$ & $\begin{array}{c}63.149 \\
(97.101)\end{array}$ & $\begin{array}{c}-93.278 \\
(104.332)\end{array}$ & $\begin{array}{c}-108.590 \\
(129.486)\end{array}$ \\
\hline No & Yes & Yes & Yes \\
\hline Yes & Yes & Yes & Yes \\
\hline 0.97 & 0.99 & 0.98 & 0.97 \\
\hline 279 & 279 & 279 & 279 \\
\hline
\end{tabular}

\section{Discussion of the Results}

The results presented here should be interpreted with caution, because there are various considerable limitations to the present study. First of all, the OBOR initiative is a very young project and the railways investigated here have only operated for a few years. Therefore, there are some serious restrictions in the availability of relevant data. Its main contribution to the young literature on OBOR is the identification of a statistically significant positive effect of the railway infrastructure expansion on the trade of several categories of goods, which is in line with the assumptions of the gravity model and other reviewed studies.

Secondly, the countries included in this study are not a random sample but rather a convenience sample, including the countries, which were connected by railway and the EU-25 countries as a control group. The study can be un-
Table 6:

Regression on log SITC 8 (imports)

\begin{tabular}{|c|c|c|}
\hline Predictor & $\begin{array}{c}\text { logsitc8 (imports) } \\
\text { No year }\end{array}$ & $\begin{array}{c}\text { logsitc8 (imports) } \\
\text { /w year }\end{array}$ \\
\hline $\begin{array}{l}\text { Railway } \\
\text { connection }\end{array}$ & $\begin{array}{l}0.359 \\
(0.124)^{* *}\end{array}$ & $\begin{array}{c}0.358 \\
(0.128)^{* *}\end{array}$ \\
\hline Tariff & $\begin{array}{l}0.094 \\
(0.013)^{* *}\end{array}$ & $\begin{array}{l}0.095 \\
(0.014)^{* *}\end{array}$ \\
\hline Distance & $\begin{array}{l}0.000 \\
(0.000)^{* *}\end{array}$ & $\begin{array}{l}0.000 \\
(0.000)^{* *}\end{array}$ \\
\hline $\begin{array}{l}\text { Exchange rate } \\
\text { (Yuan-USD) }\end{array}$ & $\begin{array}{l}-0.658 \\
(0.082)^{* *}\end{array}$ & $\begin{array}{l}-0.665 \\
(0.120)^{* *}\end{array}$ \\
\hline $\begin{array}{l}\text { Exchange rate } \\
\text { (Yuan-Euro) }\end{array}$ & $\begin{array}{l}0.190 \\
(0.056)^{* *}\end{array}$ & $\begin{array}{l}0.189 \\
(0.057)^{* *}\end{array}$ \\
\hline Landlocked & $\begin{array}{l}-0.993 \\
(0.496)^{*}\end{array}$ & $\begin{array}{l}-0.987 \\
(0.476)^{*}\end{array}$ \\
\hline GDP & $\begin{array}{c}0.000 \\
(0.000)\end{array}$ & $\begin{array}{c}0.000 \\
(0.000)\end{array}$ \\
\hline Chinese GDP & $\begin{array}{l}-0.000 \\
(0.000)\end{array}$ & $\begin{array}{l}-0.000 \\
(0.000)\end{array}$ \\
\hline Constant & $\begin{array}{l}7.668 \\
(1.418)^{* *}\end{array}$ & $\begin{array}{c}21.858 \\
(132.984)\end{array}$ \\
\hline Year dummy & No & Yes \\
\hline Country dummy & Yes & Yes \\
\hline$R^{2}$ & 0.98 & 0.98 \\
\hline N & 279 & 279 \\
\hline
\end{tabular}

Robust standard errors controlling for clusters in parentheses: ${ }^{*} p<0.05 ;{ }^{* *} p<0.01$

derstood as a semi-natural experiment, where the establishment of a rail connection between some countries and China is seen as the main independent factor, which explains the outcome variables (trade figures). This study design cannot be expected to have the same statistical validity and absence of bias as a fully randomized experiment. Lastly, there is a small chance that the effects of the rail connections observed here are caused by some confounding variable. Although all possible efforts to include the relevant control variables in the study were made, it is possible that the rail connections themselves are caused by certain political, geographical, or other country-specific factors which also explain the effects on trade, and which were not controlled for. Nevertheless, we think that the present study is statistically and logically sound, and that the results can be used as approximations of the true effects of the railways. 
A striking result of our analysis was that there is no significant effect of the railway connections on the overall exports to China. This result may be explained by the fact that up to now many of the OBOR trains carry goods from China to other markets, but return to China empty or with little cargo on board. In the long term, it can be expected that the trains' capacities will be more extensively used to export products to China. If this is the case, future replications of this study should deliver a significant result for the export data. The only significant effect found for the export data was a 100 percent increase of exports of food and animals to China. The possibility that the short travel time of the intercontinental trains enables the export of perishable goods from European producers to Chinese markets should be considered as an explanation for this effect.

A significant positive effect of the rail connections on the import of Chinese goods was found. Therefore, our initial hypothesis can be confirmed. The new rail connections of the OBOR initiative have a positive effect on the trade be- tween China and its trading partners which are connected by rail. The analysis of individual SITC categories showed that the import of laptops and other electrical appliances does not increase more than general imports do as a result of the railways. Rather, the import of miscellaneous manufactured articles (SITC 8 ) profits the most from the railway initiative.

Therefore, by and large, the results seem to align with the core assumptions of the studies, which have been reviewed above. The general consensus of studies focusing on infrastructure's impact on trade is that the revealed impact is positive. The main idea behind these studies is that lower transportation costs triggered by the expansion in infrastructure have a positive impact on imports as well as exports. In this regard, as mentioned and discussed above, our study is in line with the study by Celbis et al. (2014). Future studies on this topic can build on the applied methodological and theoretical basis forwarded in this paper in order to develop these further and find the real effects of one of the most ambitious infrastructure projects of our time.

\section{THE YUXINOU RAILWAY: CONNECTING CHONGQING AND DUISBURG BY TRAIN ${ }^{3}$}

Yuxinou was the first railway line to be promoted in the 'One Belt, One Road' initiative and started operating on January 28, 2011. It sets out from Chongqing and passes through Kazakhstan, Russia, Belarus, Poland, and finally reaches Germany in Duisburg. In March 2014, China's president, Xi Jinping, visited Duisburg where he witnessed the arrival of a cargo train at the railway station in Duisburg from Chongqing. This railway has significantly lowered the transportation time between Europe and China. This is in part due to the highly efficient customs clearance

3 This section draws on interviews that the authors conducted in Chongqing and Duisburg in 2015 and 2016. system along the railway network. If transported by sea from Chongqing to Europe, cargoes will first need to be shipped from Chongqing to Shanghai via the Yangtze River, and then carried over by sea from Shanghai to Europe. Yuxinou has reduced the transportation time on land to only two weeks (13 days) versus one and a half months by sea. Currently, every week there are four to five trains that leave Chongqing bound for Europe and three to four trains that return to Chongqing. By 2013, the transportation expense was lowered to 0.6 USD for one carriage per kilometre (Zhong 2015). This price is similar to the price by sea transport but the shipping time is much shorter, enabling the railway to be competitive to sea transport. 
To be sure, the 'One Belt, One Road' initiative only just started a few years ago and there is still a very long way to go for railway transportation to grow in importance as compared to the world's dominating mode of transportation, ocean shipping, which accounts for 95 percent of total shipping. However, available data suggests that there is a clear trend of Yuxinou's growing importance: Until the end of 2015, Yuxinou operated 453 times, including 347 times from China to Europe and 106 times from Europe to China. That 220 of these exchanges took place in 2015 alone illustrates the railways' increasingly growing importance.

The 'One Belt, One Road' Initiative's biggest advantage in general and the Yuxinou railway in particular, is that it makes it possible to connect China and Europe in a quick and inexpensive way. It is a middle ground approach between deep sea transportation and air shipping, because it mixes ocean shipping's advantage of low costs with air shipping's advantage of rapidity of transportation. Yuxinou heavily reduces ocean shipping's transportation time (by 20 days) and also decreases the high price of air shipping (by 80 percent). Yuxinou is operated by the YuXinOu Logistics Company Ltd., a joint venture between Russian, Chinese, Kazakh, and German railway companies. This multinational cooperation ensures that the goods exchanges are smooth and unimpeded by imperfect knowledge of foreign circumstances.

Duisburg does not only act as the nominal starting and end point of the Yuxinou railway in Eu- rope, but also as a distribution centre that can link Europe and China. Taking exchanges from Europe to China as an example, this means that goods from Western European countries, such as Spain, France, Belgium or the Netherlands, arrive in Duisburg where they are consigned and loaded onto one of the Yuxinou railway trains by Duisport, a German logistics company. From Duisburg, these goods then are transferred to Małaszewicze in Poland or Brest in Belarus where the trains are placed onto other tracks to fit the broader gauge size of former Soviet countries, i.e. Russia and Kazakhstan. This procedure takes between one and two days. Afterwards, the goods proceed on their journey to China, e.g. to Chongqing.

The "Yuxinou" railway is expected to have positive effect on local employment. Around 300 logistics oriented companies are based in the port of Duisburg. In total over 20,000 jobs in Duisburg depend on the port. The railway connection also increases Duisburg's fame in China. Following the new railway line's operation, and especially after Xi Jinping's official visit to Duisburg in 2014, many Chinese local governments desire to cooperate with Duisburg. In 2014, Nanjing High Accurate Drive Equipment Manufacturing, a Chinese company, established its European headquarters in Duisburg due to the railways' operations. It can be expected that in the future Duisburg and its nearby region will attract more and more Chinese companies and also an increasing number of Chinese tourists.

\section{CONCLUSION}

Trade relations between China, Central Asia and Europe have existed for centuries. The 'One Belt One Road' initiative aims at deepening this historical relationship by improving infrastructural and organizational capabilities along the Belt and Road. One of this initiative's crucial elements is the establishment of intercontinental railways, which directly connect China with Europe. These railways offer a competitive and faster alternative to the transport of goods via sea routes, and may increase the intensity of international trade through a reduction of transport costs.

We investigate this assumption by means of a multiple regression analysis. The results demonstrate that the railways increase the intensi- 
ty of trade between China and its trading partners along the 'New Silk Road.' This holds true for the import of Chinese products, but only to a very limited extent for the export of European and Central Asian products to China. Due to the limitations outlined above, this result should be interpreted with caution, but it can be used as an indication towards the true effects of the railways. If trade flourishes, countries can produce according to their comparative advantages, which lead to win-win situations. Therefore, the proliferation of profitable trade is a common goal of many countries. The railways investigated here are a significant factor in achieving this goal.
'One Belt, One Road' is a project in its infancy and so is the research on its effects. This study was an attempt at bringing together the necessary data and methodological tools to arrive at a preliminary conclusion about the project's railway initiative. As significant results were achieved, further, more elaborate studies on the matter are warranted and needed. Future research should expand on the ideas developed here, adding on the amount of data collected and the statistical methods used. As the OBOR project matures, studies should be able to find more distinct results. It might be worthwhile to carry out a longitudinal follow-up to this study, to investigate the project's effects and profitability over time.

\section{REFERENCES}

Berthelon, Matias / Caroline Freund (2004): On the Conservation of Distance in International Trade. World Bank Policy Research Paper 3293.

Brooks, Douglas H. (2009): Infrastructure's role in lowering Asia's trade costs. In: Douglas H. Brooks and David Hummels (eds.): Infrastructure's Role in Lowering Asia's Trade Costs. Cheltenham, UK / Northampton, MA, USA: Edward Elgar, 1-16.

Calderón, César / Luis Servén (2004): The Effects of Infrastructure Development on Growth and Income Distribution. Central Bank of Chile Working Paper 270.

Celbiş, Mehmet G. / Peter Nijkamp / Jacques Poot (2014): Infrastructure and Trade: A Meta-Analysis. In: The Journal of ERSA 1(1), 25-65.

Deng, Jingjin (2015): "Yuxinou”, weihe duzhan'aotou (Why "Yuxinou" plays the most important role). In: Hunan Daily, June 17, retrieved from: http://hnrb.voc. com.cn/hnrb_epaper/html/2015-06/17/content_ 983825.htm?div=-1, last accessed on: August 30, 2015 .

Donaldson, Dave (2012): Railroads of the Raj: Estimating the Impact of Transportation Infrastructure. NBER Working Paper 16487.

Donaldson, Dave / Richard Hornbeck (2013): Railroads and American Economic Growth: A "Market Access" Approach. NBER Working Paper 19213.
Egger, Peter / Mario Larch (2008): The Bilateral and Multilateral Trade Effects of Road and Railway Transport Infrastructure. Retrieved from: http://www. eea-esem.com/files/papers/EEA-ESEM/2008/266/ Larch.pdf, last accessed on: August 30, 2015.

Egorova, Kira (2015): China launches the world's largest freight train route. In: Russia Beyond the Headlines, June 16, retrieved from: http://rbth.com/business/2015/06/16/china_launches_the_worlds_longest_freight_train_route_46921.html, last accessed on: November 25, 2015.

He, Liqiong (2012): 'Sumanou' huolie kaitong poji nisi jizhuangxiang yuncheng jilu ('Sumanou' railway line breaks the Guinness World Record of highest container freight). In: People's Daily Online, November 23, retrieved from: http://js.people.com.cn/html/2012/ 11/23/188301.html, last accessed on: August 30 , 2015.

Henan Daily (2013): 11 yueqi "Zhengou" banlie mei zhouyi ban (From November, the "Zhengou" trains will operate weekly). November 3, retrieved from: http://newpaper.dahe.cn/hnrb/html/2013-11/03/ content_979454.htm?div=1, last accessed on: August 30, 2015 .

Hummels, David (2007): Transportation Costs and International Trade in the Second Era of Globalization. In: Journal of Economic Perspectives 21(3), 131-154. 
Kepaptsoglou, Konstantinos / Matthew G. Karlaftis / Dimitrios Tsamboulas (2010): The Gravity Model Specification for Modeling International Tarde Flows and Free Trade Agreement Effects: A 10-Year Review of Empirical Studies. In: The Open Economics Journal (3), 1-13

Lin, Justin Y. (2015): 'One Belt and One Road' and Free Trade Zones - China's New Opening-up Initiatives. In: Frontier of Economics in China 10(4), 585-590.

Liu, Yang (2015): Shoutang "Yixinou" zhong'ou banlie manzai "nianhuo" dida yiwu (The first trip of the EU-China train "Yixinou" arrived in Yiwu full of stockings). In: Xinhuanet, February 22, retrieved from: http://news.xinhuanet.com/world/2015-02/22/c_ 1114416425.htm, last accessed on August 30, 2015.

NDRC (2015): Vision and Actions on Jointly Building Silk Road Economic Belt and 21st-Century Maritime Silk Road. Retrieved from: http://en.ndrc.gov.cn/ newsrelease/201503/t20150330_669367.html, last accessed on: April 16, 2016.

Nordas, Hildegunn K. / Roberta Piermartini (2004): Infrastructure and Trade. Staff Working Paper ERSD-2004-04, World Trade Organization, retrieved from: http://econstor.eu/bitstream/10419/90657/2/ 772238901.pdf, last accessed on: November 26, 2015.

Porojan, Anca (2001): Trade Flows and Spatial Effects: The Gravity Model Revisited. In: Open Economies Review 12, 265-280.

Seneviratne, Dulani / Yan Sun (2013): Infrastructure and Income Distribution in ASEAN-5: What are the Links? IMF Working Paper 13/41.

The European Commission (2015): Trade. April 22. retrieved from: http://ec.europa.eu/trade/policy/ countries-and-regions/countries/china/, last accessed on: July 15, 2015.

The Hong Kong Trade Development Council (2015): One Belt One Road: Yuxinou Railway Development.
August 11, retrieved from: https://globalconnections. hsbc.com/hong-kong/en/articles/one-belt-one-roadyuxinou-railway-development, last accessed on November 26, 2015

Xin, Chen (2013): China-EU Trade and Economic Relations (2003-2013). Working Paper Series on European Studies 7(7), Institute of European Studies, Chinese Academy of Social Sciences, retrieved from: http://ies.cass.cn/en/UploadFiles_8765/201312/ 2013122009212382.pdf, last accessed on August 31, 2015

Xinhuanet (2014): "Hanxinou" yunxing yi nian chukou fayun chaoguo 3300 biaoxiang ("Hanxinou" shipped more than 3,300 export TEUs after running for one year). April 23, retrieved from: http://news.xinhuanet. com/fortune/2015-04/23/c_1115067478.htm, last accessed on: August 30, 2015.

Yang, Fu (2015): Rongou kuaitie kaipi xiandai sichou zhilu (Rongou Express Railway opened a Modern Silk Road). In: Chengdu Daily, January 5, retrieved from: http://www.cdrb.com.cn/html/2015-01/05/content_ 2170557.htm, last accessed on: August 30, 2015.

Yin, Ru (2015): 'Hexinou' guoji huoyun banlie xi yanzhi deguo ('Hexinou' International Freight Trains go West to Germany). In: Hefei Online, June 27, retrieved from: http://news.hf365.com/system/2015/06/27/ 014647465.shtml, last accessed on: August 30, 2015.

Zhang, Qiong (2014): Hunan-Europe freight transport rail to open soon. Official website of Changsha, China, October 16, retrieved from: http://en.changsha.gov. cn/news/Local/201410/t20141016_646367, last accessed on: November 25, 2015.

Zhong, Jingrui (2015): 'Yuxinou' datong ouya jingji dadongmai ('Yuxinou' opens up Eurasian Economic Arterial Road). In: People's Daily Overseas Edition, February 25, retrieved from http://paper.people.com.cn/ rmrbhwb/html/2015-02/25/content_1536663.htm, last accessed on: August 30, 2015. 


\section{WORKING PAPERS ON EAST ASIAN STUDIES BACK ISSUES}

No. 108 / 2016 Thomas Heberer: Strategic Behavior of Private Entrepreneurs in China - Collective Action, Representative Claims, and Connective Action

No. 107 / 2016 Torsten Heinrich, Shuanping Dai: Diversity of Firm Sizes, Complexity, and Industry Structure in the Chinese Economy

No. 106 / 2015 Ralf Bebenroth, Kai Oliver Thiele: Identification to Oneself and to the Others: Employees' Perceptions after a Merger

No. 105 / 2015 Jun Gu, Annika Mueller, Ingrid Nielsen, Jason Shachat, Russell Smyth: Reducing Prejudice through Actual and Imagined Contact: A Field Experiment with Malawian Shopkeepers and Chinese Immigrants

No. 104 / 2015 Marcus Conlé: Architectural Innovation in China. The Concept and its Implications for Institutional Analysis

No. 103 / 2015 Kai Duttle, Tatsuhiro Shichijo: Default or Reactance? Identity Priming Effects on Overconfidence in Germany and Japan

No. 102 / 2015 Martin Hemmert: The Relevance of Interpersonal and Inter-organizational Ties for Interaction Quality and Outcomes of Research Collaborations in South Korea

No. 101 / 2015 Shuanping Dai, Wolfram Elsner: Declining Trust in Growing China. A Dilemma between Growth and Socio-Economic Damage

No. 99 / 2014 Anna L. Ahlers, Thomas Heberer, Gunter Schubert: 'Authoritarian Resilience' and Effective Policy Implementation in Contemporary China - A Local State Perspective

No. 98 / 2014 Werner Pascha: The Potential of Deeper Economic Integration between the Republic of Korea and the EU, Exemplified with Respect to E-Mobility

No. 97 / 2014 Anja Senz, Dieter Reinhardt (Eds.): Task Force: Connecting India, China and Southeast Asia - New Socio-Economic Developments

No. 96 / 2014 Markus Taube: Grundzüge der wirtschaftlichen Entwicklung und ihre ordnungspolitischen Leitbilder in der VR China seit 1949

No. 95 / 2013 Yasuo Saeki, Sven Horak: The Role of Trust in Cultivating Relation-specific Skills - The Case of a Multinational Automotive Supplier in Japan and Germany

No. 94 / 2013 Heather Xiaoquan Zhang, Nicholas Loubere: Rural Finance, Development and Livelihoods in China

No. 93 / 2013 Thomas Heberer, Anja Senz (Hg.): Task Force: Wie lässt sich die Zusammenarbeit des Landes NordrheinWestfalen mit China und den NRW-Partnerprovinzen vertiefen?
No. 92 / 2013 Sven Horak: Cross-Cultural Experimental Economics and Indigenous Management Research - Issues and Contributions

No. 91 / 2013 Jann Christoph von der Pütten, Christian Göbel (Hg.): Task Force: Gewerkschaften, Arbeitsmarktregulierung und Migration in China

No. 90 / 2012 Thomas Heberer: Some Reflections on the Current Situation in China

No. 89 / 2011 Susanne Löhr, René Trappel (Hg.): Task Force: Nahrungsmittel in China - Food-Security- und FoodSafety-Problematik in China

No. 88 / 2011 Peter Thomas in der Heiden: Chinese Sectoral Industrial Policy Shaping International Trade and Investment Patterns - Evidence from the Iron and Steel Industry

No. 87 / 2010 Marcus Conlé: Health Biotechnology in China: National, Regional, and Sectoral Dimensions

No. 86 / 2010 Anja Senz, Dieter Reinhardt (eds.): Green Governance - One Solution for Two Problems? Climate Change and Economic Shocks: Risk Perceptions and Coping Strategies in China, India and Bangladesh

No. 85 / 2010 Heather Xiaoquan Zhang: Migration, Risk and Livelihoods: A Chinese Case

No. 84 / 2010 Marcus Conlé, Markus Taube: Anatomy of Cluster Development in China: The case of health biotech clusters

No. 83 / 2010 Sven Horak: Aspects of Inner-Korean Relations Examined from a German Viewpoint

No. 82 / 2010 Thomas Heberer, Anja-D. Senz (Hg.): Chinas Rolle in den internationalen Beziehungen - globale Herausforderungen und die chinesische Außenpolitik

No. 81 / 2009 Flemming Christiansen, Heather Xiaoquan Zhang: The Political Economy of Rural Development in China: Reflections on Current Rural Policy

No. 80 / 2009 Chan-Mi Strüber: Germany's Role in the Foreign Direct Investment Configuration of Korean Multinational Enterprises in Europe

No. 79 / 2009 Thomas Heberer, Anja-D. Senz (Hg.): Task Force: Entwicklungspolitik und -strategien in Ostasien am Beispiel der chinesischen Umweltpolitik

No. 78 / 2008 Werner Pascha, Cornelia Storz: How are Markets Created? The Case of Japan's Silver Market

No. 77 / 2008 Werner Pascha, Uwe Holtschneider (Hg.) Task Force: Corporate Social Responsibility in Japan und Österreich 
No. 76 / 2008 Yu Keping: China's Governance Reform from 1978 to 2008

No. 75 / 2008 Thomas Heberer: Task Force: Entwicklungspolitik in China: Herausforderungen, Lösungsstrategien und deutsch-chinesische Entwicklungszusammenarbeit

No. 74 / 2008 Markus Taube: Ökonomische Entwicklung in der VR China. Nachholendes Wachstum im Zeichen der Globalisierung

No. 73 / 2007 Norifumi Kawai, Manja Jonas: Ownership Strategies in Post-Financial Crisis South-East Asia: The Case of Japanese Firms

No. 72 / 2007 Werner Pascha, Cornelia Storz, Markus Taube (Eds.): Workshop Series on the Role of Institutions in East Asian Development - Institutional Foundations of Innovation and Competitiveness in East Asia

No. 71 / 2006 Norifumi Kawai: Spatial Determinants of Japanese Manufacturing Firms in the Czech Republic

No. 70 / 2006 Werner Pascha, Cornelia Storz (Hg.): Workshop Institutionen in der Entwicklung Ostasiens I - Offenheit und Geschlossenheit asiatischer Wirtschaftssysteme

No. 69 / 2006 Christian Göbel: The Peasant's Rescue from the Cadre? An Institutional Analysis of China's Rural Tax and Fee Reform

No. 68 / 2006 Thomas Heberer: Institutional Change and Legitimacy via Urban Elections? People's Awareness of Elections and Participation in Urban Neighbourhoods (Shequ)

No. 67 / 2006 Momoyo Hüstebeck: Tanaka Makiko: Scharfzüngige Populistin oder populäre Reformerin?

No. 66 / 2006 Momoyo Hüstebeck: Park Geun-hye: Als Präsidententochter zur ersten Staatspräsidentin Südkoreas?

No. 65 / 2006 Werner Pascha, Cornelia Storz (Hg.): Workshop Organisation und Ordnung der japanischen Wirtschaft V. Themenschwerpunkt: Deutschlandjahr in Japan - eine Zwischenbilanz

No. 64 / 2004 Christian Göbel, Thomas Heberer (Hg.): Task Force: Zivilgesellschaftliche Entwicklungen in China / Task Force: Civil Societal Developments in China

No. 63 / 2005 Thorsten Nilges: Zunehmende Verschuldung durch Mikrokredite. Auswertung eines Experiments in Südindien

No. 62 / 2004 Jun Imai: The Rise of Temporary Employment in Japan. Legalisation and Expansion of a Non-Regular Employment Form

No. 61 / 2004 Thomas Heberer, Nora Sausmikat: Bilden sich in China Strukturen einer Zivilgesellschaft heraus?

No. 60 / 2004 Thomas Heberer, Anja Senz (Hg.): Feldforschung in Asien: Erlebnisse und Ergebnisse aus der Sicht politikwissenschaftlicher Ostasienforschung
No. 59 / 2004 Li Fan: Come by the Wind. Li Fan's Story in Buyun Election

No. 58 / 2004 Li Minghuan: Labour Brokerage in China Today: Formal and Informal Dimensions

No. 57 / 2004 Dorit Lehrack: NGO im heutigen China Aufgaben, Rolle und Selbstverständnis

No. 56 / 2004 Anja Senz: Wählen zwischen Recht und Pflicht - Ergebnisse einer Exkursion der Ostasienwissenschaften in die Provinz Sichuan / VR China

No. 55 / 2004 Werner Pascha, Cornelia Storz: Workshop Organisation und Ordnung der japanischen Wirtschaft IV. Themenschwerpunkt: Wahrnehmung, Institutionenökonomik und Japanstudien

No. 54 / 2004 Thomas Heberer: Ethnic Entrepreneurs as Agents of Social Change. Entrepreneurs, clans, social obligations and ethnic resources: the case of the Liangshan $\mathrm{Yi}$ in Sichuan

No. 53 / 2003 Hermann Halbeisen: Taiwan's Domestic Politics since the Presidential Elections 2000

No. 52 / 2003 Claudia Derichs, Wolfram Schaffar (Hg.): Task Force: Interessen, Machstrukturen und internationale Regime. Die WTO-Verhandlungen zum GATS (Dienstleistungsabkommen) und sein Einfluss auf Asien

No. 51 / 2003 Markus Taube: Chinas Rückkehr in die Weltgemeinschaft. Triebkräfte und Widerstände auf dem Weg zu einem „Global Player“

No. 50 / 2003 Kotaro Oshige: Arbeitsmarktstruktur und industrielle Beziehungen in Japan. Eine Bestandsaufnahme mit Thesen zur Zukunftsentwicklung

No. 49 / 2003 Werner Pascha, Cornelia Storz (Hg.): Workshop Organisation und Ordnung der japanischen Wirtschaft III. Themenschwerpunkt: Institutionenökonomik und Japanstudien

No. 48 / 2003 Institute of East Asian Studies (Ed.), Frank Robaschik (compilation), with contributions from Winfried Flüchter, Thomas Heberer, Werner Pascha, Frank Robaschik, Markus Taube: Overview of East Asian Studies in Central and Eastern Europe

No. 47 / 2002 Ulrich Zur-Lienen: Singapurs Strategie zur Integration seiner multi-ethnischen Bevölkerung: Was sich begegnet gleicht sich an

No. 46 / 2002 Thomas Heberer: Strategische Gruppen und Staatskapazität: Das Beispiel der Privatunternehmer in China

No. 45 / 2002 Thomas Heberer, Markus Taube: China, the European Union and the United States of America: Partners or Competitors?

No. 44 / 2002 Werner Pascha: Wirtschaftspolitische Reformen in Japan - Kultur als Hemmschuh? 
No. 43 / 2002 Werner Pascha, Klaus Ruth, Cornelia Storz (Hg.): Themenschwerpunkt: Einfluss von IT-Technologien auf Strukturen und Prozesse in Unternehmen

No. 42 / 2002 Karin Adelsberger, Claudia Derichs, Thomas Heberer, Patrick Raszelenberg: Der 11. September und die Folgen in Asien. Politische Reaktionen in der VR China, Japan, Malaysia und Vietnam

No. 41 / 2001 Claudia Derichs, Thomas Heberer (Hg.): Task Force: Ein Gutachten zu Beschäftigungspolitik, Altersvorsorge und Sozialstandards in Ostasien

No. 40 / 2001 Werner Pascha, Frank Robaschik: The Role of Japanese Local Governments in Stabilisation Policy

No. 39 / 2001 Anja Senz, Zhu Yi: Von Ashima zu Yi-Rap: Die Darstellung nationaler Minderheiten in den chinesischen Medien am Beispiel der Yi-Nationalität

No. 38 / 2001 Claudia Derichs: Interneteinsatz in den Duisburger Ostasienwissenschaften: Ein Erfahrungsbericht am Beispiel des deutsch-japanischen Seminars „DJ50“

No. 37 / 2001 Zhang Luocheng: The particularities and major problems of minority regions in the middle and western parts of China and their developmental strategy

No. 36 / 2001 Thomas Heberer: Falungong - Religion, Sekte oder Kult? Eine Heilsgemeinschaft als Manifestation von Modernisierungsproblemen und sozialen Entfremdungsprozessen

No. 35 / 2001 Claudia Derichs, Thomas Heberer, Patrick Raszelenberg (Hg.): Task Force: Ein Gutachten zu den politischen und wirtschaftlichen Beziehungen Ostasien-NRW

No. 34 / 2000 Ulrich Jürgens, Werner Pascha, Cornelia Storz (Hg.): Workshop Organisation und Ordnung der japanischen Wirtschaft I. Themenschwerpunkt: „New Economy“ - Neue Formen der Arbeitsorganisation in Japan

No. 33 / 2000 Winfried Flüchter: German Geographical Research on Japan

No. 32 / 2000 Thomas Heberer, Sabine Jakobi: Henan The Model: From Hegemonism to Fragmentism. Portrait of the Political Culture of China's Most Populated Province

No. 31 / 2000 Thomas Heberer: Some Considerations on China's Minorities in the 21st Century: Conflict or Conciliation?

No. 30 / 2000 Jun Imai, Karen Shire: Flexible Equality: Men and Women in Employment in Japan

No. 29 / 2000 Karl Lichtblau, Werner Pascha, Cornelia Storz (Hg.): Workshop Klein- und Mittelunternehmen in Japan V. Themenschwerpunkt: M \& A in Japan - ein neues Instrument der Unternehmenspolitik?

No. 28 / 1999 Rainer Dormels: Regionaler Antagonismus in Südkorea
No. 27 / 1999 Claudia Derichs, Tim Goydke, Werner Pascha (Hg.): Task Force: Ein Gutachten zu den deutschen/europäischen Außen- und Außenwirtschaftsbeziehungen mit Japan

No. 26 / 1999 Susanne Steffen: Der Einsatz der Umweltpolitik in der japanischen Elektrizitätswirtschaft

No. 25 / 1999 Claudia Derichs: Nationbuilding in Malaysia under Conditions of Globalization

No. 24 / 1999 Thomas Heberer, Arno Kohl, Tuong Lai, Nguyen Duc Vinh: Aspects of Privat Sector Development in Vietnam

No. 23 / 1999 Werner Pascha: Corruption in Japan An Economist's Perspective

No. 22 / 1999 Nicole Bastian: Wettbewerb im japanischen Fernsehmarkt. Neue Strukturen durch Kabel- und Satellitenfernsehen? Eine wettbewerbstheoretische Analyse

No. 21 / 1999 Thomas Heberer: Entrepreneurs as Social Actors: Privatization and Social Change in China and Vietnam

No. 20 / 1999 Vereinigung für sozialwissenschaftliche Japan-Forschung (Hg.): Quo vadis sozialwissenschaftliche Japan-Forschung? Methoden und Zukunftsfragen

No. 19 / 1999 Bong-Ki Kim: Das Problem der interkulturellen Kommunikation am Beispiel der Rezeption Deweys in China

No. 18 / 1998 Werner Pascha, Cornelia Storz (Hg.): Workshop Klein- und Mittelunternehmen in Japan IV. Themenschwerpunkt Netzwerke

No. 17 / 1998 Andreas Bollmann, Claudia Derichs, Daniel Konow, Ulrike Rebele, Christian Schulz, Kerstin Seemann, Stefanie Teggemann, Stephan Wieland: Interkulturelle Kompetenz als Lernziel

No. 16 / 1997 Werner Pascha, Cornelia Storz (Hg.): Workshop Klein- und Mittelunternehmen in Japan III. Themenschwerpunkt Innovation

No. 15 / 1997 Winfried Flüchter: Tokyo quo vadis? Chancen und Grenzen (?) metropolitanen Wachstums

No. 14 / 1997 Claudia Derichs: Der westliche Universalitätsanspruch aus nicht-westlicher Perspektive

No. 13 / 1997 Werner Pascha: Economic Globalization and Social Stabilization: A Dual Challenge for Korea

No.12 / 1996 Claudia Derichs: Kleine Einführung in die Politik und das politische System Japans

No. 11 / 1996 Mikiko Eswein: Die Rolle der Berufsbildung beim sozialen Wandel in Japan

No. 10 / 1996 Mikiko Eswein: Erziehung zwischen Konfuzianismus und Bismarck. Schule und Erziehungssystem in Japan 
No. 9 / 1996 Werner Pascha: On the Relevance of the German Concept of "Social Market Economy" for Korea

No. 8 / 1996 Carsten Herrmann-Pillath: Strange Notes on Modern Statistics and Traditional Popular Religion in China: Further Reflections on the Importance of Sinology for Social Science as applied on China

No. 7 / 1996 Ralph Lützeler: Die japanische Familie der Gegenwart - Wandel und Beharrung aus demographischer Sicht

No. 6 / 1995 Werner Pascha (Hg.): Klein- und Mittelunternehmen in Japan - Dokumentation eines Workshops

No. 5 / 1995 Chen Lai: Die Kultur des Volkskonfuzianismus: Eine Untersuchung der Literatur zur kindlichen Erziehung (Meng xue)
No. 4 / 1995 Carsten Herrmann-Pillath: Die Volksrepublik und die Republik China: Die Gratwanderung zweier chinesischer Staaten zwischen Politik und Wirtschaft

No. 3 / 1995 Carsten Herrmann-Pillath: On the Importance of Studying Late Qing Economic and Social History for the Analysis of Contemporary China or: Protecting Sinology Against Social Science

No. 2 / 1995 H. J. Beckmann, K. Haaf, H. Kranz, W. Pascha, B. Slominski, T. Yamada: „Japan im Netz". Eine Materialsammlung zur Nutzung des Internet

No. 1 / 1995 Claudia Derichs, Winfried Flüchter, Carsten Herrmann-Pillath, Regine Mathias, Werner Pascha: Ostasiatische Regionalstudien: Warum? 
No. 109 (2016): The Effect of the New Silk Road Railways on Aggregate Trade Volumes between China and Europe

Li, Yuan; Bolton, Kierstin; Westphal, Theo

In: Working papers on East Asian studies / 2016

Dieser Text wird über DuEPublico, dem Dokumenten- und Publikationsserver der Universität Duisburg-Essen, zur Verfügung gestellt.

Die hier veröffentlichte Version der E-Publikation kann von einer eventuell ebenfalls veröffentlichten Verlagsversion abweichen.

DOI: https://doi.org/10.17185/duepublico/48112

URN: urn:nbn:de:hbz:464-20190212-142503-1

Link: https://duepublico.uni-duisburg-essen.de:443/servlets/DocumentServlet?id=48112 